\title{
Influence of Obesity and Type 2 Diabetes Mellitus on the Pharmacokinetics of Tramadol After Single Oral Dose Administration
}

\author{
Joanna Porażka ${ }^{1}(1) \cdot$ Edyta Szałek $^{1} \cdot$ Wojciech Połom ${ }^{2} \cdot$ Mateusz Czajkowski $^{2} \cdot$ Tomasz Grabowski $^{3}$. \\ Marcin Matuszewski ${ }^{2} \cdot$ Edmund Grześkowiak $^{1}$
}

Published online: 18 February 2019

(c) The Author(s) 2019

\begin{abstract}
Background and Objectives The number of overweight, obese and diabetic patients is constantly increasing. Metabolic disorders may affect the pharmacokinetics of drugs, e.g., by altering the activity of cytochrome P450 (CYP) isoenzymes. Tramadol is a commonly used analgesic metabolised mainly via CYP2D6 to its active metabolite, $O$-desmethyltramadol. The aim of the study was to assess the influence of overweight, obesity and type 2 diabetes mellitus on tramadol and $O$-desmethyltramadol pharmacokinetics.

Methods All patients received a single oral dose $(100 \mathrm{mg})$ of tramadol. The plasma concentrations of tramadol and $O$-desmethyltramadol were measured with the validated high-performance liquid chromatography method with fluorescence detection. The pharmacokinetic parameters of tramadol and $O$-desmethyltramadol were calculated by non-compartmental methods. Results After nephrectomy, the patients were divided into four groups - a control group ( $n=12$, mean [SD] age 61 [14] years, body mass index (BMI) 22 [2] kg/m ${ }^{2}, \mathrm{CL}_{\mathrm{cr}}$ (creatinine clearance) 74 [30] $\left.\mathrm{mL} / \mathrm{min}\right)$; an overweight group $(n=15$, mean [SD] age 63 [11] years, BMI 27 [1] kg/m², $\mathrm{CL}_{\mathrm{cr}} 81$ [35] mL/min); an obese group ( $n=12$, mean [SD] age 57 [8] years, BMI 33 [4] kg/m $\mathrm{m}^{2}, \mathrm{CL}_{\mathrm{cr}} 113$ [51] mL/min); and an obese and diabetic group ( $n=9$, mean [SD] age 64 [10] years, BMI 33 [4] kg/m², $\left.\mathrm{CL}_{\mathrm{cr}} 87[35] \mathrm{mL} / \mathrm{min}\right)$. Apart from the time to first occurrence of maximal concentration $\left(t_{\max }\right.$, there were no significant differences in the pharmacokinetic parameters of tramadol and $O$-desmethyltramadol among the groups. Moreover, there were no significant differences in the $O$-desmethyltramadol/tramadol ratios among the four groups of patients after nephrectomy. Conclusions No significant differences were found in the pharmacokinetics of tramadol and $O$-desmethyltramadol, indicating that the opioid can be administered to overweight, obese and diabetic patients without dosage adjustment.
\end{abstract}

\section{Key Points}

Obesity significantly decreases the $t_{\max }$ of tramadol and its metabolite, $O$-desmethyltramadol.

No additional influence on the pharmacokinetics of tramadol and $O$-desmethyltramadol was observed in patients with coexistence of type 2 diabetes mellitus.

Joanna Porażka

joanna.porazka@gmail.com

1 Department of Clinical Pharmacy and Biopharmacy, Poznań University of Medical Sciences, ul. Św. Marii Magdaleny 14, 61-861 Poznań, Poland

2 Department of Urology, Medical University of Gdansk, ul. Smoluchowskiego 17, 80-214 Gdańsk, Poland

3 Polpharma Biologics, ul. Trzy lipy 3, 80-172 Gdańsk, Poland

\section{Introduction}

Obesity and diabetes mellitus are growing global health problems. According to the latest WHO report, in 2014, $8.5 \%$ of the world's adult population suffered from diabetes mellitus and $12.1 \%$ was obese $[1,2]$. Both diseases often coexist and cause a wide range of pathophysiological alterations. Increased blood volume, liver blood flow, cardiac output and glomerular filtration, which are observed in obese patients, may affect drug pharmacokinetics [3]. In diabetes mellitus, changes in gastric emptying, non-enzymatic glycation of albumin, the activity of cytochrome P450 (CYP) isoenzymes and excretion may also influence drug gastrointestinal absorption, distribution, biotransformation and elimination [4]. Many patients who require postoperative treatment of pain are obese and/or have diabetes mellitus. Previous studies have reported the effect of obesity and/or 
diabetes mellitus on the pharmacokinetics of many drugs [5-7]. Tramadol is an analgesic used for treating moderate to moderately severe acute and chronic pain. This opioid is routinely administered to treat postoperative pain.

The drug is characterised by dual mechanism of action. It is a monoaminergic reuptake inhibitor and opioid receptor agonist. Approximately $80 \%$ of tramadol is metabolised via CYP2D6 to its active metabolite, $O$-desmethyltramadol and via CYP3A4 and CYP2B6 to $N$-desmethyltramadol. $O$-desmethyltramadol is approximately 200 times more potent than the parent drug [8].

Studies concerning alterations in CYP2D6 activity in diabetic and obese patients are still inconsistent. Although in vitro studies have confirmed that lipid accumulation decreases the activity of CYP2D6, the results of in vivo studies are not consistent $[6,9]$. It is not known if changes in CYP2D6 activity may have clinical significance to drug metabolism in obese patients. Taheri et al. observed decreased activity of CYP2D6 in diabetic rats, but the difference was not statistically significant. However, altered CYP2D6 expression was not observed in TSOD (Tsumura, Suzuki, Obese, Diabetes) mice [10].

The aim of our study was to assess the influence of obesity and type 2 diabetes mellitus on the pharmacokinetics of orally administered tramadol.

\section{Methods}

\subsection{Reagents}

Tramadol, $O$-desmethyltramadol and venlafaxine were purchased from LGC Standards (Poland). High-performance liquid chromatography (HPLC) grade acetonitrile, methanol, diethyl ether, heptane, ethyl acetate, and orthophosphoric acid were purchased from Merck (Poland). Sodium phosphate dibasic was purchased from Sigma-Aldrich (Poland). Water used in the mobile phase was deionised, distilled and filtered through a Millipore system before use. Tramadol (batch: 313H01, expiration date: 02.2021) was purchased from Stada (Germany).

\subsection{Subjects}

Patients who underwent nephrectomy between February and October 2017 were the research subjects. The patients were included in the study if they met the following criteria-total or partial nephrectomy; age > 18 years; no history of allergy to tramadol; pain $>7$ (visual analogue scale). The control group consisted of patients with a body mass index (BMI) of $<25 \mathrm{~kg} / \mathrm{m}^{2}$; the overweight group consisted of patients with a BMI between 25 and $29.9 \mathrm{~kg} / \mathrm{m}^{2}$; the obese group consisted of patients with a BMI of $\geq 30 \mathrm{~kg} / \mathrm{m}^{2}$; and the obese and diabetic group consisted of patients with a BMI of $\geq 30 \mathrm{~kg} / \mathrm{m}^{2}$ and type 2 diabetes mellitus. The chief exclusion criteria were previous tramadol exposure, administration of ondansetron, administration of monoamine oxidase inhibitors within 14 days before the study, uncontrolled epilepsy (continuing to experience seizures despite appropiate treatment), severe renal insufficiency (glomerular filtration rate [GFR] between 15 and $29 \mathrm{~mL} / \mathrm{min} / 1.73 \mathrm{~m}^{2}$ ) and severe hepatic insufficiency (B or C on Child-Pugh scale) [11-13]. The baseline characteristics of all 48 patients enrolled in the research are shown in Table 1. Creatinine clearance was calculated for each patient using the Cockroft-Gault formula from the creatinine concentration value obtained on the day of sample collection. All patients provided written consent to participate in the study.

\subsection{Drug Administration and Blood Sampling}

Tramadol was administered to the patients at a single oral dose of $100 \mathrm{mg}$ (two capsules, Tramadol; Stada) with $200 \mathrm{~mL}$ of water on an empty stomach on the second day after nephrectomy. Blood samples $(2 \mathrm{~mL})$ were collected with a peripheral venous catheter immediately before and at $0.5 \mathrm{~h}, 1 \mathrm{~h}, 1.5 \mathrm{~h}, 2 \mathrm{~h}, 2.5 \mathrm{~h}, 4 \mathrm{~h}, 6 \mathrm{~h}, 8 \mathrm{~h}, 12 \mathrm{~h}$ and $24 \mathrm{~h}$ after drug administration. The blood samples were transferred into heparinised tubes and centrifuged at 2,880 $\mathrm{g}$ for $10 \mathrm{~min}$ at $4{ }^{\circ} \mathrm{C}$. The plasma was then transferred to propylene tubes and stored at $-80^{\circ} \mathrm{C}$ until analysis.

\subsection{Drug Assay}

The concentrations of tramadol and $O$-desmethyltramadol were determined using the HPLC method with fluorescence detection (HPLC-FL) [14]. Separation was achieved by isocratic elution of the mobile phase, sodium phosphate dibasic $0.1 \mathrm{M}$ pH 3.3 (adjusted with $85 \%$ orthophosphoric acid)-acetonitrile $(7: 3, \mathrm{v} / \mathrm{v})$, at a flow rate of $1.0 \mathrm{~mL} / \mathrm{min}$ through an ODS-A C18 column $(250 \mathrm{~mm} \times 4.6 \mathrm{~mm}, 5.0 \mu \mathrm{m}$ particle size) (YMC). The column temperature was maintained at $25{ }^{\circ} \mathrm{C}$. The FL detection wavelength was set at $\lambda_{\mathrm{ex}}=275 \mathrm{~nm} / \lambda_{\mathrm{em}}=300 \mathrm{~nm}$ and the injection volume was $50 \mu \mathrm{L}$. Venlafaxine was used as an internal standard. Separation of stereoisomers was not achieved under used conditions. Total analysis time for each run was $9 \mathrm{~min}$. The lower limits of quantification (LLOQ) for tramadol and $O$-desmethyltramadol were $5 \mathrm{ng} / \mathrm{mL}$ and $3 \mathrm{ng} / \mathrm{mL}$, respectively. Intra- and inter-day precision and accuracy of the LLOQ, low quality control $(15 \mathrm{ng} / \mathrm{mL}$ and $9 \mathrm{ng} / \mathrm{mL})$, medium quality control $(500 \mathrm{ng} / \mathrm{mL}$ and $50 \mathrm{ng} / \mathrm{mL})$, and high quality control $(600 \mathrm{ng} / \mathrm{mL}$ and $80 \mathrm{~mL})$ for tramadol and $O$-desmethyltramadol were well within the acceptable limit of $15 \%$ coefficient of variation (CV\%). The calibration was linear and ranged from 5.0 to $700.0 \mathrm{ng} / \mathrm{mL}(r=0.998)$ for tramadol 
Table 1 Patient characteristics

\begin{tabular}{|c|c|c|c|c|c|}
\hline Parameter & Control group & Overweight patients & Obese patients & $\begin{array}{l}\text { Obese and } \\
\text { diabetic } \\
\text { patients }\end{array}$ & $p$ value \\
\hline Males/females & $8 / 4$ & $13 / 2$ & $10 / 2$ & $7 / 2$ & - \\
\hline Age [years] & $\begin{array}{l}61 \pm 14 \\
(32-86)\end{array}$ & $\begin{array}{l}63 \pm 11 \\
(39-74)\end{array}$ & $\begin{array}{l}57 \pm 8 \\
(43-71)\end{array}$ & $\begin{array}{l}64 \pm 10 \\
(47-81)\end{array}$ & $>0.05$ \\
\hline Weight $[\mathrm{kg}]$ & $\begin{array}{l}67 \pm 8 \\
(57-79)\end{array}$ & $\begin{array}{l}84 \pm 17 * \\
(60-107)\end{array}$ & $\begin{array}{l}100 \pm 17 * \\
(80-142)\end{array}$ & $\begin{array}{l}89 \pm 14^{*} \\
(56-105)\end{array}$ & $<0.05$ \\
\hline BMI $\left[\mathrm{kg} / \mathrm{m}^{2}\right]$ & $\begin{array}{l}22 \pm 2 \\
(24-18)\end{array}$ & $\begin{array}{l}27 \pm 1^{*} \\
(25-29)\end{array}$ & $\begin{array}{l}33 \pm 4^{*} \\
(30-43)\end{array}$ & $\begin{array}{l}33 \pm 4^{*} \\
(30-41)\end{array}$ & $<0.05$ \\
\hline WHR & $\begin{array}{l}0.88 \pm 0.05 \\
(0.83-0.97)\end{array}$ & $\begin{array}{l}0.97 \pm 0.07 * \\
(0.85-1.05)\end{array}$ & $\begin{array}{l}1.16 \pm 0.14^{*} \\
(1.04-1.4)\end{array}$ & $\begin{array}{l}1.09 \pm 0.08^{*} \\
(1.00-1.19)\end{array}$ & $<0.05$ \\
\hline $\mathrm{S}_{\mathrm{cr}}[\mathrm{mg} / \mathrm{dL}]$ & $\begin{array}{l}1.02 \pm 0.24 \\
(0.64-1.4)\end{array}$ & $\begin{array}{l}1.14 \pm 0.38 \\
(0.63-1.64)\end{array}$ & $\begin{array}{l}0.88 \pm 0.3 \\
(0.58-1.72)\end{array}$ & $\begin{array}{l}1.12 \pm 0.28 \\
(0.84-1.19)\end{array}$ & $>0.05$ \\
\hline $\mathrm{CL}_{\mathrm{cr}}[\mathrm{mL} / \mathrm{min}]$ & $\begin{array}{l}74 \pm 30 \\
(36-136)\end{array}$ & $\begin{array}{l}81 \pm 35 \\
(39-142)\end{array}$ & $\begin{array}{l}113 \pm 51 \\
(60-233)\end{array}$ & $\begin{array}{l}87 \pm 35 \\
(32-129)\end{array}$ & $>0.05$ \\
\hline $\mathrm{GFR}\left[\mathrm{mL} / \mathrm{min} / 1.73 \mathrm{~m}^{2}\right]$ & $\begin{array}{l}67 \pm 20 \\
(44-89)\end{array}$ & $\begin{array}{l}57 \pm 21 \\
(24-81)\end{array}$ & $\begin{array}{l}72.3 \pm 17 \\
(37-90)\end{array}$ & $\begin{array}{l}60 \pm 20 \\
(28-80)\end{array}$ & $>0.05$ \\
\hline INR & $\begin{array}{l}1.0 \pm 0.1 \\
(0.8-1.2)\end{array}$ & $\begin{array}{l}1.0 \pm 0.1 \\
(0.9-1.1)\end{array}$ & $\begin{array}{l}1.1 \pm 0.1 \\
(0.9-1.2)\end{array}$ & $\begin{array}{l}1.0 \pm 0.2 \\
(0.8-1.2)\end{array}$ & $>0.05$ \\
\hline
\end{tabular}

Values are expressed as mean \pm SD (range); *Significantly increased compared to controls

$B M I$ body mass index, WHR waist-to-hip ratio, $S_{c r}$ creatinine concentration, $C L_{c r}$ creatinine clearance estimated by the Cockroft-Gault formula, GFR glomerular filtration rate, INR international normalised ratio

and from 3.0 to $80.0 \mathrm{ng} / \mathrm{mL}(r=0.999)$ for $O$-desmethyltramadol. Samples were prepared by adding $1 \mathrm{~mL}$ of plasma, $50 \mu \mathrm{L}$ of $7.5 \mu \mathrm{g} / \mathrm{mL}$ venlafaxine solution (internal standard), $400 \mu \mathrm{L}$ of $0.1 \mathrm{M}$ sodium hydroxide and $4.0 \mathrm{~mL}$ extraction mixture (heptan:ethyl acetate:ether) to $10-\mathrm{mL}$ glass tubes. The samples were then vortexed for $10 \mathrm{~min}$ and centrifuged at $2,880 \mathrm{~g}$ for $10 \mathrm{~min}$. Then, $3.4 \mathrm{~mL}$ of the upper organic phase was collected and completely evaporated under a steam of nitrogen gas at a temperature of $50{ }^{\circ} \mathrm{C}$. The dry residue was reconstituted in $80 \mu \mathrm{L}$ mobile phase, which was heated in a hot bath at $40{ }^{\circ} \mathrm{C}$ and vortexed. The solution was put into inserts and $20 \mu \mathrm{L}$ was injected into the HPLC system.

\subsection{Pharmacokinetic Analysis}

The pharmacokinetic parameters were estimated by means of non-compartmental methods, using computer software (Phoenix WinNonlin ${ }^{\circledR}$ v. 6.3; Certara L.P., USA). The following pharmacokinetic parameters were calculated-maximum plasma concentration $\left(\mathrm{C}_{\max }\right)$, time to first occurrence of $\mathrm{C}_{\max }\left(T_{\max }\right)$, apparent volume of distribution $\left(\mathrm{V}_{\mathrm{d}} / \mathrm{F}\right)$, elimination half-life $\left(t_{1 / 2 \mathrm{kel}}\right)$, elimination rate constant $\left(\mathrm{k}_{\mathrm{el}}\right)$, clearance (CL), mean residence time (MRT), area under the plasma concentration-time curve from zero to the time of the last measurable concentration $\left(\mathrm{AUC}_{0-t}\right)$, and area under the first moment curve from zero to the time of the last measurable concentration $\left(\mathrm{AUMC}_{0-t}\right)$.

\subsection{Statistical Analysis}

Differences in the pharmacokinetic parameter values were tested by one-way analysis of variance (ANOVA) in PROC GLM of the SAS package (SAS System for Windows, ver. 9.3; SAS Institute Inc., Cary, NC, USA). Tukey's test was applied for post hoc comparisons among all the groups. Differences that generated $p$ values $<0.05$ were considered statistically significant.

\section{Results}

The anthropometric and biochemical parameters of all the groups of patients are shown in Table 1 . The patients after nephrectomy were characterised by the following parameters-a control group (mean [SD] age 61 [14] years, BMI 22 [2] kg/m ${ }^{2}, \mathrm{CL}_{\mathrm{cr}} 74$ [30] $\mathrm{mL} / \mathrm{min}$ ); an overweight group $\left(n=15\right.$, mean [SD] age 63 [11] years, BMI $27[1] \mathrm{kg} / \mathrm{m}^{2}$, $\left.\mathrm{CL}_{\mathrm{cr}} 81[35] \mathrm{mL} / \mathrm{min}\right)$; an obese group $(n=12$, mean [SD] age 57 [8] years, BMI 33 [4] kg/m², $\mathrm{CL}_{\mathrm{cr}} 113$ [51] mL/min); and an obese and diabetic group $(n=9$, mean [SD] age 64 [10] years, BMI 33 [4] kg/m², $\mathrm{CL}_{\mathrm{cr}} 87$ [35] mL/min). The groups of patients did not differ significantly in age and biomarkers of renal function [serum creatinine concentrations $\left(\mathrm{S}_{\mathrm{cr}}\right), \mathrm{CL}_{\mathrm{cr}}$ and GFR]. However, the GFR and $\mathrm{CL}_{\mathrm{cr}}$ values estimated with the Cockroft-Gault formula were lower than normal in 12 and 29 patients, respectively. Two patients (one patient in the obese group and one in the obese and 


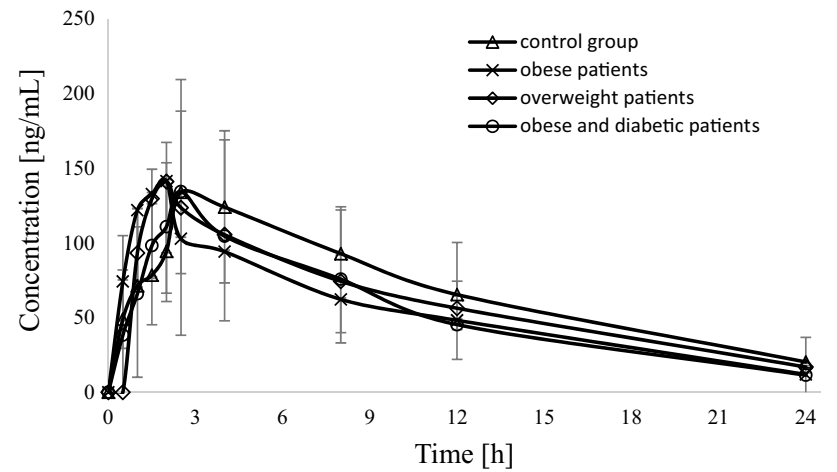

Fig. 1 The tramadol plasma concentration-time profile following single oral administration of $100 \mathrm{mg}$ of tramadol to patients after nephrectomy

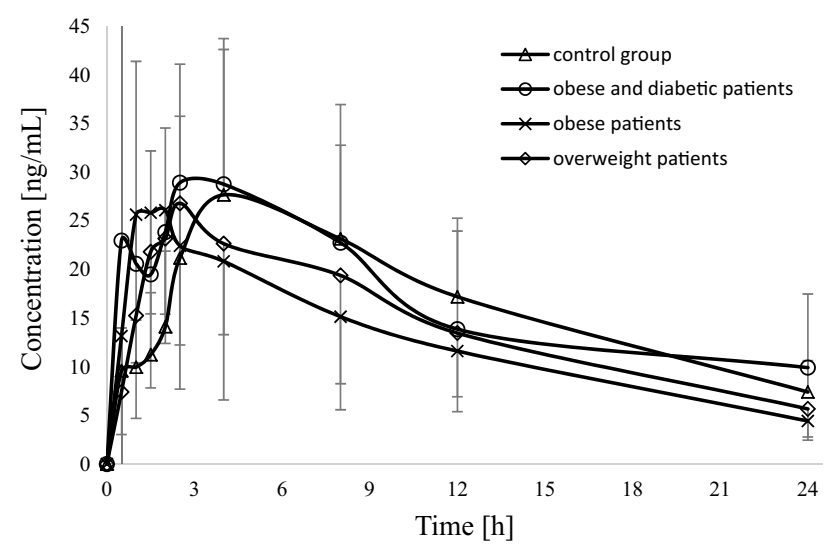

Fig. 2 The $O$-desmethyltramadol plasma concentration-time profile following singe oral administration of $100 \mathrm{mg}$ of tramadol to patients after nephrectomy

diabetic group) suffered from morbid obesity (BMI $>40 \mathrm{~kg} /$ $\mathrm{m}^{2}$ ). Figures 1 and 2 show the arithmetic mean plasma concentration-time profiles of tramadol and its metabolite. Table 2 shows the pharmacokinetic parameters of tramadol and $O$-desmethyltramadol in the four groups of patients. The CV\% exceeded $30 \%$ for most of the pharmacokinetic parameters, indicating high inter-subject variability. The $t_{\max }$ values of tramadol and $O$-desmethyltramadol in the group of obese patients $(1.58 \pm 0.93 \mathrm{~h}$ and $2.17 \pm 2.06 \mathrm{~h}$, respectively) were significantly lower than in the control group $(2.88 \pm 0.93 \mathrm{~h})$. Moreover, the $t_{\max }$ value of $O$-desmethyltramadol was shorter in the group of overweight patients $(2.61 \pm 1.69 \mathrm{~h})$. However, there was no difference in the $t_{\max }$ between the obese patients with diabetes and the control group. The four groups of patients did not differ significantly in the following pharmacokinetic parameters of the parent drug and its metabolite $-\mathrm{C}_{\max }, \mathrm{AUC}_{0-t}, \mathrm{AUMC}_{0-t}, \mathrm{MRT}, \mathrm{k}_{\mathrm{el}}$, $t_{1 / 2 \mathrm{kel}}, \mathrm{CL} / \mathrm{F}, \mathrm{V}_{\mathrm{d}} / \mathrm{F}$. The $O$-desmethyltramadol/tramadol ratios for $\mathrm{C}_{\max }$ and $\mathrm{AUC}_{0-t}$ were also similar.
Only 2 of 48 patients reported adverse events after the administration of tramadol. One patient from the control group had nausea and vomiting. One patient from the overweight group suffered from dizziness and anxiety.

\section{Discussion}

To the best of our knowledge, there have been no studies concerning the pharmacokinetics of tramadol and its metabolite $O$-desmethyltramadol in overweight, obese and diabetic subjects after nephrectomy. In our study we found that neither overweight nor obesity had a significant effect on the pharmacokinetic parameters of tramadol and its active metabolite $O$-desmethyltramadol (except $t_{\max }$ ). The $t_{\max }$ of the opioid and its metabolite in the obese patients was significantly lower than in the control group. Moreover, the $t_{\max }$ of $O$-desmethyltramadol was significantly decreased in overweight patients compared to the control group. We did not observe statistically significant differences in the values of $O$-desmethyltramadol/tramadol ratios among studied groups. Additionally, the pharmacokinetic parameters of tramadol and $O$-desmethyltramadol were similar in the obese subjects with diabetes and in the obese group.

The patients did not receive CYP2D6 inhibitors, except one obese subject, who received fluoxetine (20 mg per day). The inhibitory effect of fluoxetine was manifested by the patient's higher tramadol plasma concentrations and lower $O$-desmethyltramadol plasma concentrations.

The pharmacokinetics of analgesic drugs were investigated in earlier studies on metabolic disorders. Hoogd et al. did not observe the influence of morbid obesity on morphine plasma concentrations. However, the decreased clearance of morphine-3-glucuronide and morphine-6-glucuronide in morbidly obese patients may result in increased exposure to metabolites [5]. The $\mathrm{C}_{\max }$ and AUC of paracetamol were increased, whereas the $\mathrm{V}_{\mathrm{d}} / \mathrm{F}$ and $\mathrm{CL} / \mathrm{F}$ were decreased in patients with morbid obesity [10].

Furthermore, the pharmacokinetics of tramadol in metabolic disorders have been studied previously. Morales et al. observed reduced AUC and increased fraction unbound of (-)-O-desmethyltramadol in patients with type 1 and type 2 diabetes mellitus; however, we did not observe any alterations in the exposure to tramadol and $O$-desmethyltramadol [7].

Lavasani et al. found that the concentrations of $O$-desmethyltramadol in the liver of diabetic rats were higher than in the control group and the $O$-desmethyltramadol/ tramadol ratios in diabetic rats were significantly higher than in the control group [10]. Kudo et al. found that the activity of CYP2D6 was not altered in TSOD mice [9]. We also did not observe any significant differences in $O$-desmethyltramadol/tramadol ratios between the obese patients 
Table 2 The pharmacokinetic parameters of tramadol and $O$-desmethyltramadol in patients after nephrectomy

\begin{tabular}{|c|c|c|c|c|c|}
\hline PK parameter & Control group & Overweight patients & Obese patients & Obese and diabetic patients & $p$ value \\
\hline \multicolumn{6}{|l|}{ Tramadol } \\
\hline $\begin{array}{l}\mathrm{AUC}_{0-t} \\
{[\mathrm{ng} \cdot \mathrm{h} / \mathrm{mL}]}\end{array}$ & $1,120.76 \pm 437.39(39.03)$ & $\begin{array}{l}1,024.39 \pm 332.53 \\
(32.46)\end{array}$ & $\begin{array}{l}946.46 \pm 351.39 \\
(37.13)\end{array}$ & $\begin{array}{l}894.81 \pm 409.32 \\
(45.74)\end{array}$ & $>0.05$ \\
\hline $\begin{array}{l}\mathrm{AUMC}_{0-t} \\
{\left[\mathrm{ng} \cdot \mathrm{h}^{2} / \mathrm{mL}\right]}\end{array}$ & $\begin{array}{l}6,435.75 \pm 2,561.01 \\
(39.79)\end{array}$ & $\begin{array}{l}5,489.34 \pm 2,067.51 \\
(37.66)\end{array}$ & $\begin{array}{l}4,801.71 \pm 1,946.96 \\
(40.55)\end{array}$ & $\begin{array}{l}4,526.62 \pm 2,306.38 \\
(50.95)\end{array}$ & $>0.05$ \\
\hline $\begin{array}{l}\mathrm{MRT}_{0-t} \\
{[\mathrm{~h}]}\end{array}$ & $\begin{array}{l}5.78 \pm 0.52 \\
(9.06)\end{array}$ & $\begin{array}{l}5.33 \pm 0.90 \\
(16.84)\end{array}$ & $\begin{array}{l}5.11 \pm 0.72 \\
(14.06)\end{array}$ & $\begin{array}{l}5.00 \pm 1.01 \\
(20.09)\end{array}$ & $>0.05$ \\
\hline $\begin{array}{c}\mathrm{K}_{\mathrm{el}} \\
{\left[\mathrm{h}^{-1}\right]}\end{array}$ & $\begin{array}{l}0.08 \pm 0.05 \\
(57.26)\end{array}$ & $\begin{array}{l}0.09 \pm 0.04 \\
(41.66)\end{array}$ & $\begin{array}{l}0.09 \pm 0.04 \\
(39.55)\end{array}$ & $\begin{array}{l}0.09 \pm 0.05 \\
(50.11)\end{array}$ & $>0.05$ \\
\hline $\begin{array}{l}t_{1 / 2 \mathrm{kel}} \\
{[\mathrm{h}]}\end{array}$ & $\begin{array}{l}13.01 \pm 12.46 \\
(95.80)\end{array}$ & $\begin{array}{l}9.13 \pm 5.47 \\
(59.90)\end{array}$ & $\begin{array}{l}8.93 \pm 3.84 \\
(42.96)\end{array}$ & $\begin{array}{l}11.83 \pm 12.20 \\
(103.13)\end{array}$ & $>0.05$ \\
\hline $\begin{array}{l}\mathrm{C}_{\max } \\
{[\mathrm{ng} / \mathrm{mL}]}\end{array}$ & $\begin{array}{l}146.83 \pm 58.19 \\
(39.63)\end{array}$ & $\begin{array}{l}159.09 \pm 42.94 \\
(26.99)\end{array}$ & $\begin{array}{l}174.23 \pm 77.61 \\
(44.55)\end{array}$ & $\begin{array}{l}157.36 \pm 70.31 \\
(44.69)\end{array}$ & $>0.05$ \\
\hline $\begin{array}{l}t_{\max } \\
{[\mathrm{h}]}\end{array}$ & $\begin{array}{l}2.88 \pm 0.93 \\
(32.43)\end{array}$ & $\begin{array}{l}2.40 \pm 1.71 \\
(71.39)\end{array}$ & $\begin{array}{l}1.58 \pm 0.93 \\
(58.44)^{*}\end{array}$ & $\begin{array}{l}2.28 \pm 0.87 \\
(38.20)\end{array}$ & $<0.05$ \\
\hline $\begin{array}{l}\mathrm{Cl} / \mathrm{F} \\
{[1 / \mathrm{h} / \mathrm{kg}]}\end{array}$ & $\begin{array}{l}1.6 \pm 0.7 \\
(47.12)\end{array}$ & $\begin{array}{l}1.4 \pm 0.5 \\
(37.67)\end{array}$ & $\begin{array}{l}1.2 \pm 0.4 \\
(35.61)\end{array}$ & $\begin{array}{l}1.4 \pm 0.5 \\
(34.96)\end{array}$ & $>0.05$ \\
\hline $\mathrm{V}_{\mathrm{d}} / \mathrm{F}[1 / \mathrm{kg}]$ & $\begin{array}{l}9.2 \pm 4.8 \\
(52.21)\end{array}$ & $\begin{array}{l}7.5 \pm 3.9 \\
(51.71)\end{array}$ & $\begin{array}{l}6.2 \pm 3.1 \\
(48.91)\end{array}$ & $\begin{array}{l}7.2 \pm 3.0 \\
(41.07)\end{array}$ & $>0.05$ \\
\hline \multicolumn{6}{|c|}{$O$-desmethyltramadol } \\
\hline $\begin{array}{l}\mathrm{AUC}_{0-t} \\
{[\mathrm{ng} \cdot \mathrm{h} / \mathrm{mL}]}\end{array}$ & $\begin{array}{l}244.55 \pm 130.91 \\
(53.53)\end{array}$ & $\begin{array}{l}231.04 \pm 87.33 \\
(37.80)\end{array}$ & $\begin{array}{l}205.17 \pm 91.72 \\
(44.72)\end{array}$ & $\begin{array}{l}254.78 \pm 109.48 \\
(42.97)\end{array}$ & $>0.05$ \\
\hline $\begin{array}{l}\mathrm{AUMC}_{0-\mathrm{t}} \\
{\left[\mathrm{ng} \cdot \mathrm{h}^{2} / \mathrm{mL}\right]}\end{array}$ & $\begin{array}{l}1,538.98 \pm 827.47 \\
(53.77)\end{array}$ & $\begin{array}{l}1,318.08 \pm 489.25 \\
(37.12)\end{array}$ & $1,104.97 \pm 437.10(39.56)$ & $\begin{array}{l}1,422.64 \pm 773.85 \\
(54.40)\end{array}$ & $>0.05$ \\
\hline $\begin{array}{c}\mathrm{K}_{\mathrm{el}} \\
{\left[\mathrm{h}^{-1}\right]}\end{array}$ & $\begin{array}{l}0.08 \pm 0.04 \\
(49.99)\end{array}$ & $\begin{array}{l}0.07 \pm 0.05 \\
(63.24)\end{array}$ & $\begin{array}{l}0.08 \pm 0.08 \\
(98.75)\end{array}$ & $\begin{array}{l}0.11 \pm 0.05 \\
(46.29)\end{array}$ & $>0.05$ \\
\hline $\begin{array}{l}\mathrm{C}_{\max } \\
{[\mathrm{ng} / \mathrm{mL}]}\end{array}$ & $\begin{array}{l}29.62 \pm 15.85 \\
(53.53)\end{array}$ & $\begin{array}{l}30.95 \pm 13.56 \\
(43.82)\end{array}$ & $\begin{array}{l}29.85 \pm 18.00 \\
(60.31)\end{array}$ & $\begin{array}{l}38.40 \pm 15.05 \\
(41.79)\end{array}$ & $>0.05$ \\
\hline $\begin{array}{l}t_{\max } \\
{[\mathrm{h}]}\end{array}$ & $\begin{array}{l}5.13 \pm 2.24 \\
(43.66)\end{array}$ & $\begin{array}{l}2.61 \pm 1.69 \\
(64.79)^{*}\end{array}$ & $\begin{array}{l}2.17 \pm 2.06 \\
(95.06)^{* *}\end{array}$ & $\begin{array}{l}3.31 \pm 2.30 \\
(69.38)\end{array}$ & $<0.05$ \\
\hline \multicolumn{6}{|l|}{ M1/TRM } \\
\hline $\mathrm{C}_{\max }$ & $0.23 \pm 0.11(50.54)$ & $0.20 \pm 0.08(41.11)$ & $0.18 \pm 0.08(45.75)$ & $0.27 \pm 0.16(58.91)$ & $>0.05$ \\
\hline $\mathrm{AUC}_{0-t}$ & $0.27 \pm 0.18(66.28)$ & $0.24 \pm 0.12(49.85)$ & $0.25 \pm 0.09(37.03)$ & $0.3 \pm 0.15(49.48)$ & $>0.05$ \\
\hline
\end{tabular}

Values are expressed as mean $\pm \mathrm{SD}(\mathrm{CV} \%)$

*Significantly decreased compared to controls $(p$ value $<0.05)$

**Significantly decreased compared to controls $(p$ value $<0.01)$

$C_{\max }$ maximum observed plasma concentration, $t_{\max }$ time to first occurrence of $\mathrm{C}_{\max }, C l$ creatinine clearance, $V_{d} / F$ apparent volume of distribution after non-intravenous administration, $A U C_{0-t}$ area under the plasma concentration-time curve from zero to the time of last measurable concentration, $A U M C_{0-t}$ area under the first moment curve from zero to the time of last measurable concentration, $t_{1 / 2 \mathrm{kel}}$ half-life in elimination phase, $K_{e l}$ elimination rate constant, $M R T$ mean residence time, $S D$ standard deviation, $C V$ coefficient of variation

with type 2 diabetes mellitus and the control group. The significant differences in the $t_{\max }$ of tramadol and $O$-desmethyltramadol may have been caused by accelerated gastric emptying in obesity [15]. Although both obesity and diabetes were reported to increase GFR and $\mathrm{CL}_{\mathrm{cr}}$, the groups of patients after nephrectomy did not differ significantly in these parameters [16]. The elimination of tramadol and $O$-desmethyltramadol was comparable in all the groups. Moreover, in spite of the high lipophilicity of tramadol, the volume of distribution remained unchanged in the groups [17].
Uncontrolled postoperative pain causes prolonged hospitalisation, delayed recovery and decreases patient satisfaction, so appropriate pain treatment is a significant part of postoperative care. In particular, as $O$-desmethyltramadol is 200 times more potent than the parent drug, increased metabolism of tramadol may result in exacerbation of adverse events [8]. As both obesity and diabetes may affect the pharmacokinetics of drugs, it is important to select adequate analgesics for these groups of patients. As the results of our study indicate that obesity and diabetes do not affect the pharmacokinetics of tramadol, the opioid might be an 
approriate drug for obese and diabetic patients who require moderate to severe pain treatment.

The research was limited by the inclusion of patients after different types of nephrectomy (total or partial). However, there were no significant differences in the renal function between the groups. Our study was also limited by a small number of patients. Therefore, it should be continued with a larger group.

\section{Conclusions}

There were no clinically relevant alterations in the pharmacokinetics of tramadol and its active metabolite $O$-desmethyltramadol among the control, overweight, obese and obese with diabetes groups of patients. Based on the results of this study, tramadol can be administered to overweight, obese and type 2 diabetes mellitus patients without dose adjustment.

\section{Compliance with Ethical Standards}

Funding No source of funding.

Conflict of Interest Joanna Porażka, Edyta Szałek, Wojciech Połom, Mateusz Czajkowski, Tomasz Grabowski, Marcin Matuszewski, Edmund Grześkowiak have no confict of interest.

Ethical Approval All procedures performed in studies involving human participants were in accordance with the ethical standards of the institutional research committee and with the 1964 Helsinki declaration and its later amendments and approved by the by the local ethics committee at the Medical University of Gdańsk (NKBBN/73/2017).

Informed Consent Written informed consent was obtained from all patients participating in the study.

OpenAccess This article is distributed under the terms of the Creative Commons Attribution-NonCommercial 4.0 International License (http://creativecommons.org/licenses/by-nc/4.0/), which permits any noncommercial use, distribution, and reproduction in any medium, provided you give appropriate credit to the original author(s) and the source, provide a link to the Creative Commons license, and indicate if changes were made.

\section{References}

1. World Health Organization. Global report on obesity. 2016. http:// apps.who.int/iris/bitstream/10665/204871/1/9789241565257_eng. pdf?ua $=1$. Accessed 8 Feb 2018.

2. World Health Organization. Fact sheet on obesity and overweight. 2018. http://www.who.int/mediacentre/factsheets/fs311/en/. Accessed 8 Feb 2018
3. Brill M, Diepstraten J, van Rongen A, van Kralingen S, van den Anker J, Knibbe K. Impact of obesity on drug metabolism and elimination in adults and children. Clin Pharmacokinet. 2012;51:277-304.

4. Dostałek M, Akhlagh F, Puzanovova M. Effect of diabetes mellitus on pharmacokinetic and pharmacodynamic properties of drugs. Clin Pharmacokinet. 2012;51:481-99.

5. De Hoogd S, Valitalo PA, Dahan A, van Kralingen S, Coughtrie M, van Dongen E, van Ramshorst B. Influence of morbid obesity on the pharmacokinetics of morphine, morphine-3-glucuronide, and morphine-6-glucuronide. Clin Pharmacokinet. 2017;56:1577-87.

6. Goday A, Arno Farré M, Rodríguez-Morató J, Ramon JM, PérezMañá C, Papaseit E, Civit E, Langohr K, Lí Carbó M, Boix DB, Nino OC, Le Roux M, Pera M, Grande L, de la Torre R. Pharmacokinetics in morbid obesity: influence of two bariatric surgery techniques on paracetamol and caffeine metabolism. Obes Surg. 2017;27:3194-201.

7. de Moraesa N, Laurettib G, Lanchotea V. Effects of type 1 and type 2 diabetes on the pharmacokinetics of tramadol enantiomers in patients with neuropathic pain phenotyped as cytochrome P4502D6 extensive metabolizers. JPP. 2014;66:1222-30.

8. Miotto K, Cho K, Khalil M, Blanco K, Sasaki JD, Rawson R. Trends in tramadol: pharmacology, metabolism and misuse. Anesth Analg. 2017;124:44-51.

9. Kudo T, Shimada T, Toda T, Igeta S, Suzuki W, Ikarashi N, Ochiai W, Ito K, Aburada M, Sugiyama K. Altered expression of CYP in TSOD mice: a model of type 2 diabetes and obesity. Xenobiotica. 2009;39:889-902.

10. Lavasani H, Sheikholeslami B, Ardakani YH, Abdollahi M, Hakemi L, Rouini MR. Study of the pharmacokinetic changes of tramadol in diabetic rats. DARU J Pharm Sci. 2013;21:17.

11. Hao X, Goldberg D, Kelly K, Stephen L, Kwan P, Brodie MJ. Uncontrolled epilepsy is not necessarily the same as drug-resistant epilepsy: differences between populations with newly diagnosed epilepsy and chronic epilepsy. Epilepsy Behav. 2013;29:4-6.

12. Kidney Disease Improving Global Outcomes. Chapter 1: definition and classification of CKD. Kidney Int Suppl. 2013;3:19-62.

13. Talal AH, Venuto CS, Younis I. Assessment of hepatic impairment and implications for pharmacokinetics of substance use treatment. Clin Pharmacol Drug Dev. 2017;6:206-12.

14. Rouini MR, Ardakani YH, Soltani F, Aboul-Enein HY, Foroumadi A. Development and validation of a rapid HPLC method for simultaneous determination of tramadol, and its two main metabolites in human plasma. J Chromatogr B Analyt Technol Biomed Life Sci. 2006;18:207-11.

15. Jones KL, Russo A, Stevens JE, Wishart JM, Berry MK, Horowitz M. Predictors of delayed gastric emptying in diabetes. Diabetes Care. 2001;24:1264-9.

16. Stefansson V, Scheil J, Jenssen TG, Melsom T, Eriksen BO. Central obesity associates with renal hyperfiltration in the non-diabetic general population: a cross-sectional study. BMC Nephrol. 2016;17:172.

17. Costa I, Oliveira A, Guedes de Pinho P, Teixeira HM, Moreira R, Carvalho F, Dinis-Oliveira RJ. Postmortem redistribution of tramadol and $O$-desmethyltramadol. J Anal Toxicol. 2013;37:670-5. 